\title{
SIMPLIFIED METHOD FOR PREDICTION OF SETTLEMENT IN BAMBOO PILES-REINFORCED PEAT UNDER EMBANKMENT
}

\author{
Maulana Maulana ${ }^{1}$, Yudha Hanova ${ }^{1}$, Aazokhi Waruwu ${ }^{1 *}$, Erya Ratama Putra ${ }^{1}$ \\ ${ }^{1}$ Department of Civil Engineering, Institut Teknologi Medan, Indonesia
}

Analysis of settlement predicted is required to determine the appropriate time to perform additional loading and how big embankment load that can generate sufficient compression on peat soil. The settlement of peat was investigated by a program of embankment load testing. The model of tests were conducted in the laboratory to be used as a reference for etimated settlementat the certain time and load. The test result indicated that etimated settlementhas the same pattern with the pattern of observations data. This simple method can be used to estimate how long and how much embankment load is applied on peat soil up to get a addition of relatively small settlement.

Key words: Peat, Settlement, Estimated Settlement, Bamboo pile, Embankmentload

\section{INTRODUCTION}

The embankment as preloading can be conducted step by step and in a long time. Rapid embankmentload affect the stability of the embankment. Embankmenton the ground peat will experience many problems among embankment instability, stability in the lateral direction, overalls sliding, and the excessive settlement ([9]; [6]). The peat soil has a high moisture content properties, large compression, low shear strength, and low ground bearing capacity [12]. Embankment load as preloading can increase the bearing capacity of peat effectively [7]. To obtain a stable embankment, then the peat soil needs to be reinforced with reinforcement material. Reinforcement can contribute in increasing the stability of the embankment.

Initial effective stress in the peat is very low, it is very important to monitor control the rate of embankment construction in order to increase the effective stress and shear strength of peat. A strong reinforcement system limits the load embankment achieved in one construction stage, for this reason, it is necessary to have construction stages and controls on the application of embankment on peat.

Anusha and Kindo [1] using bamboo as a soil reinforcement to increase the value of the unconfined compressive strength, because of friction between the ground by the rough surface of the bamboo. Grid bamboo as a soil reinforcement can improve the compressive strength of the free [2].

Bamboo as a soil reinforcement is better than the geotextile, it is seen on the ground reinforced with bamboo and geotextile combination that produces the final settlement was smaller than reinforcement with geotextile [4].

Reinforcement of bamboo grid more than two layers looks effective in increasing the bearing capacity and reduce the settlement [13]. Reinforcement of bamboo grid difficult to implement if the peat layer is thick enough, because it requires the dismantling of the land prior to the installation of a bamboo grid. Therefore it is necessary to consider the use of bamboo piles. The combination of grid and pile bamboogrid as reinforcement of embankment on peat soil showed the ability in reducing the settlement and the deflection so that the stability of the embankment is maintained [5].

Installation of piles on a concrete slab to support the embankment is able to reduce the settlement and increase the modulus of subgrade reaction peat [12]. Liu et al. [3] states that there are several advantages of piles as supported embankment, such as implementation of embankment construction can be completed in a short time, the pile supported embankmentcan reduce total and settlement significantly, and the technical implementation of the pile corresponding the geological conditions.

High embankmentand time period of construction stage affects the stability and settlement. Because the embankment reduction can reduce soil stress, excessive settlement, and the instability of the construction. The settlement is still high causes additional embankmentcan not be conducted, because it can lead to failure of embankment construction. Therefore it is necessary analysis of expected settlement to determine the appropriate time to perform additional loading and how big embankment load that can generate sufficient compression on peat soil [11].

Some of the methods used to estimate a settlement due to embankment load such as hyperbolic and Asaokamethod. Waruwu et al. [10] states that theexpected settlement in the hyperbolic method is higher than Asaoka method, but hyperbolic method suitable for use in the measurement data with the time change is not uniform. Estimated settlement in height of the embankment and a certain time can be used as a reference in determining the stages of load on the application of embankment on the peat soil [11].

This study describes the result of settlement from the ob- 
servations and prediction in the peat soil reinforcement due to embankment load in the certain time and load. Estimated settlement use hyperbolic method with estimated coefficients of $\alpha$ and $\beta$ [11]. The purpose of this study is to estimate settlementof peat soil with reinforcement due to embankment at certain time and load. This study is expected to provide an estimate of the increase in a relatively small settlement so time and large embankment load required can be determined.

\section{RESEARCH METHODS}

The research sample using peat soils of Riau and bamboo as reinforcement of Deli Serdang, North Sumatra. Compacted peat in box test sizedof $120 \mathrm{~cm}$ x $90 \mathrm{~cm} \times 90$ $\mathrm{cm}$ in thickness every $10 \mathrm{~cm}$ to reach the thick of $50 \mathrm{~cm}$ on the gsolid layer (Figure 1) [5].

Reinforcement of peat use bamboo grid with and without bamboo pile. Bamboo pile diameter (d) of $2 \mathrm{~cm}$ and a length of $20 \mathrm{~cm}$ are distinguished based on the distance (s) in the ratio s/dof $7.5,5$, and 2.5 .

Model embankment of iron scrap sized of $1.9 \mathrm{~cm} \times 1.9$ $\mathrm{cm}$ with a length of $4 \mathrm{~cm}$ was given in stages over the surface of peat for 1 day ([1]; [12]; [5]). Embankment load produce a pressure of 1:52 kPa each layer. Stages of the load carried to five days and each additional loadingdone readings settlementon certain time and distance.

Estimated settlement use hyperbolic method froma hy-

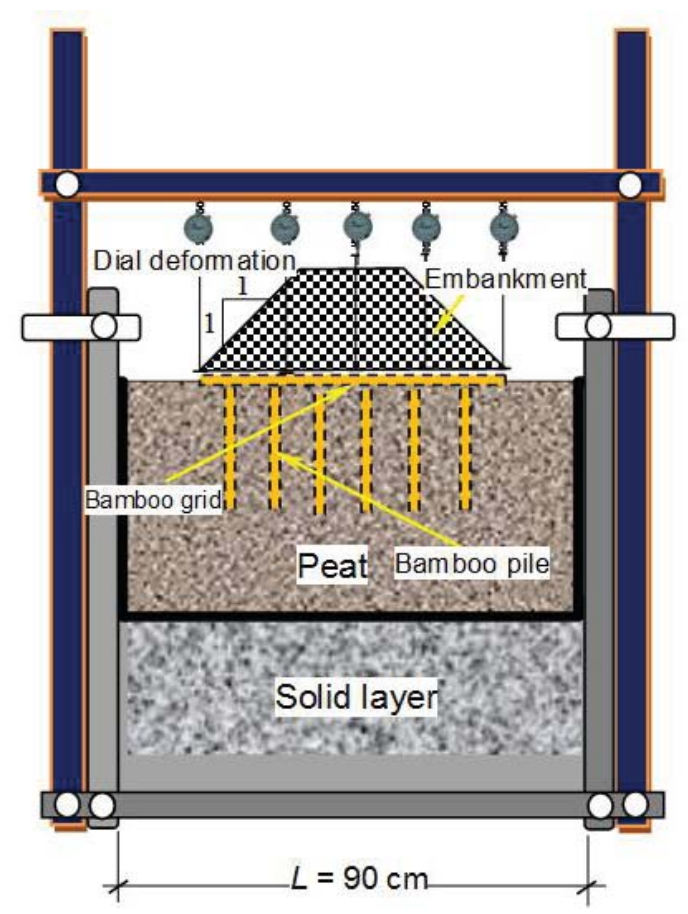

Figure 1: Model dimensions and bamboo pile configuration [5] perbolic relationship between the settlement and time. Measurement data settlement at every stage of the load and test models were used to analyze the coefficients $\alpha$ and $\beta$ of hyperbolic method[8]. A simple equation to obtain hyperbolic curve is acquired from Eq. (1) and the final settlement $\left(s_{f}\right)$ is defined by Eq. (2).

$$
\begin{aligned}
& s=\frac{t}{\alpha+\beta t} \\
& s_{f}=\frac{1}{\beta}
\end{aligned}
$$

where $\alpha$ and $\beta$ are intersection and the slope of the linear line in the relation of the ratio between $t / s$ as ordinate and $t$ as abscissa (Figure 4).

Estimated coefficient $\alpha$ and $\beta$ used methods Waruwu et al. [11]. Based on the correlation $\alpha$ coefficient and embankment load obtained estimated a coefficient in otherembankment load. The same thing wasapplied to estimatedthe $\beta$ coefficientin otherembankment load. The results of the estimated $\alpha$ and $\beta$ coefficient used to analyze the settlement and final settlement as in Eq.(1) and Eq. (2).

\section{RESULTS AND DISCUSSION \\ Result of Observation of Peat Settlement Due To Embankment}

The result of observation of peat settelement due to embenakment load is shown in Figure 2. The settlement looks quite significantly in the loading and getting smaller with increasing duration of loading. Peat compression behavior is influenced by reinforcement system. Significant compression change of peatoccurs in the use of a bamboo pile to the ratio s/d of 2.5 , while the bamboo pile to the ratio s/dof 5 and 7.5 are not much different from the grid bamboo without bamboo piles.

Each additional loading show high settlement for all types of testing, althoughchanges settlement smaller with the increasing embankment load, but the test results have not shown when and how much the load required to produce the final settlement. Thus, it need a method to estimate the embankment and time required to obtain changes insignificant settlement.

\section{Effect of Bamboo Piles Reinforcement}

Results estimated settlement at each end of the load and reduction settlement due to the use of a bamboo pile is shown in Table 1. Analysis of reduction settlement to pile distance (s) of $15 \mathrm{~cm}$ (s/dof 7.5), s of 10 (s/dof 5), and sof $5 \mathrm{~cm}(\mathrm{~s} / \mathrm{d}=2.5)$ obtained respectively $7.72 \%, 16: 52 \%$, and $48.11 \%$. The analysis showed that the bamboo pile to the ratio $\mathrm{s} / \mathrm{d}=2.5$ can reduce a significant settlement. 


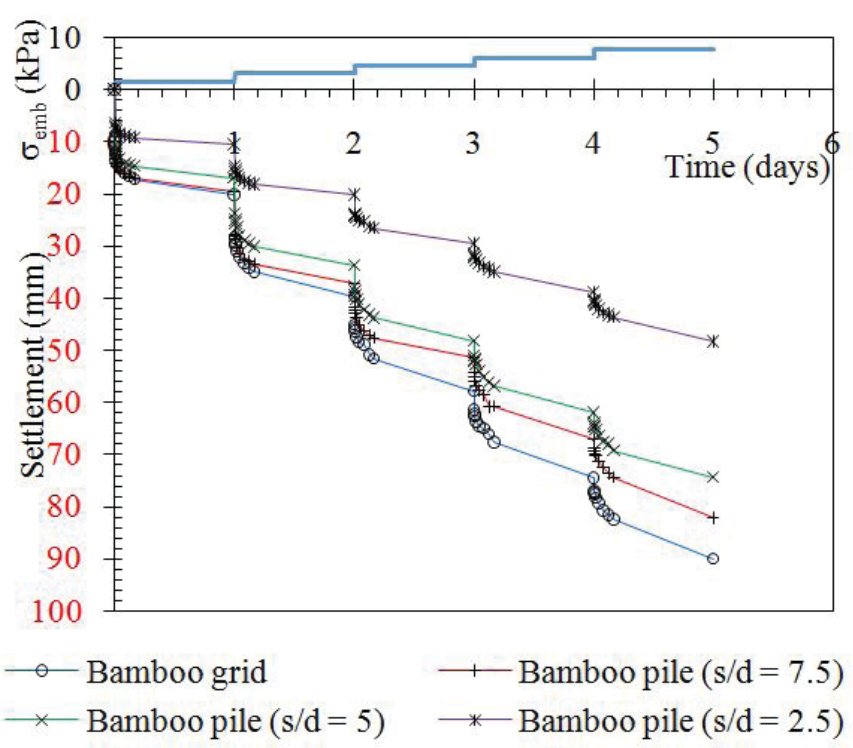

Figure 2: Result of measurement of settlement under embankment

Based on the bamboo grid width at the base of embankment (Bof $60 \mathrm{~cm}$ ) obtained correlation ratio $\mathrm{B} / \mathrm{s}$ and reduction settlement shown in Figure 3 . The close pile spaceshown the highreduction settlement, but the test results did not show how the spacethat results in maximum reduction settlement.

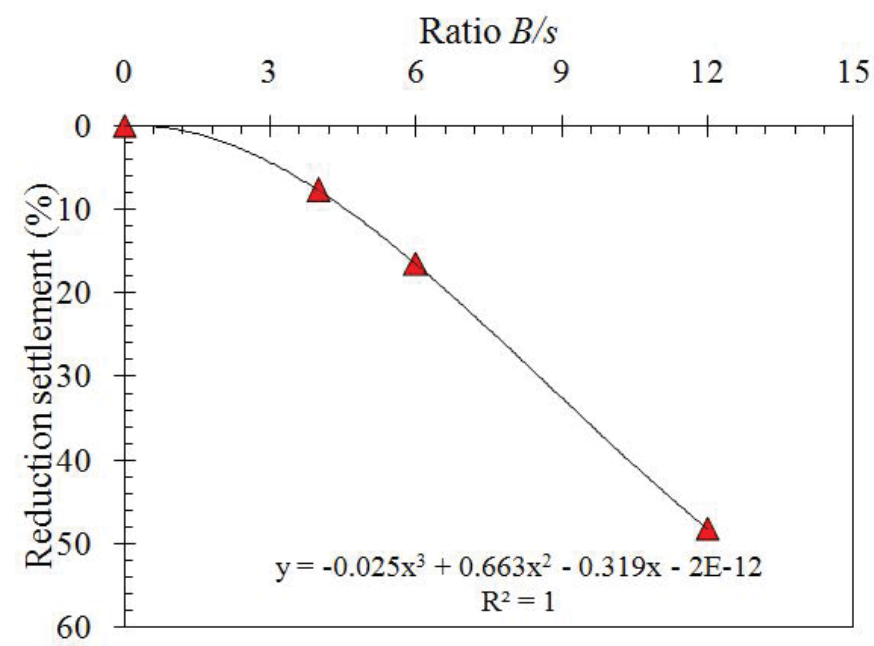

Figure 3: Correlation between ratio $\mathrm{B} / \mathrm{s}$ and reduction of settlement

Based on the regression equation for relationship $\mathrm{B} / \mathrm{s}$ and reduction settlement are obtained estimated reduction settlement in certain pile spacing (Figure 4). The results of the analysis showed that the ratio B/sof 15 provides maximum reduction settlement of about $60 \%$. The ratio $\mathrm{B} / \mathrm{s}$ of 15 obtained on the ratio s/dof 2 , thus the ratio $\mathrm{s} / \mathrm{d}$ maximum is 2 .

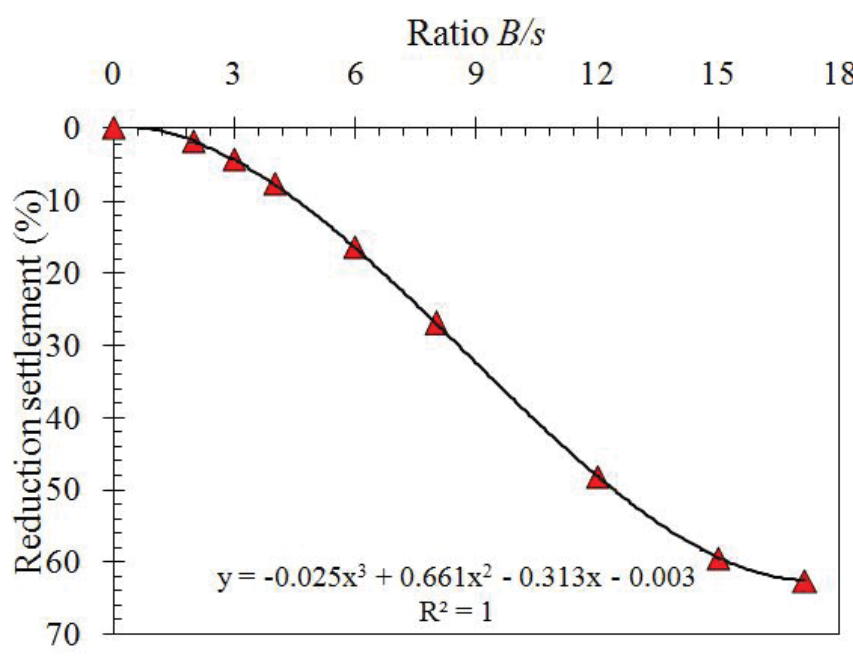

Figure 4: Correlation between ratio $\mathrm{B} / \mathrm{s}$ and reduction of settlement

\section{Results of Settlement Predicted}

Estimated settlementof hyperbolic method derived from analysis $\alpha$ and $\beta$ coefficients by making the curves $t$ and t/S as shown in Figure 5. This relationship is obtained coefficients $\alpha$ of 0.006 and coefficient $\beta$ of 0.4899 , the same thing is conducted at other test variations.

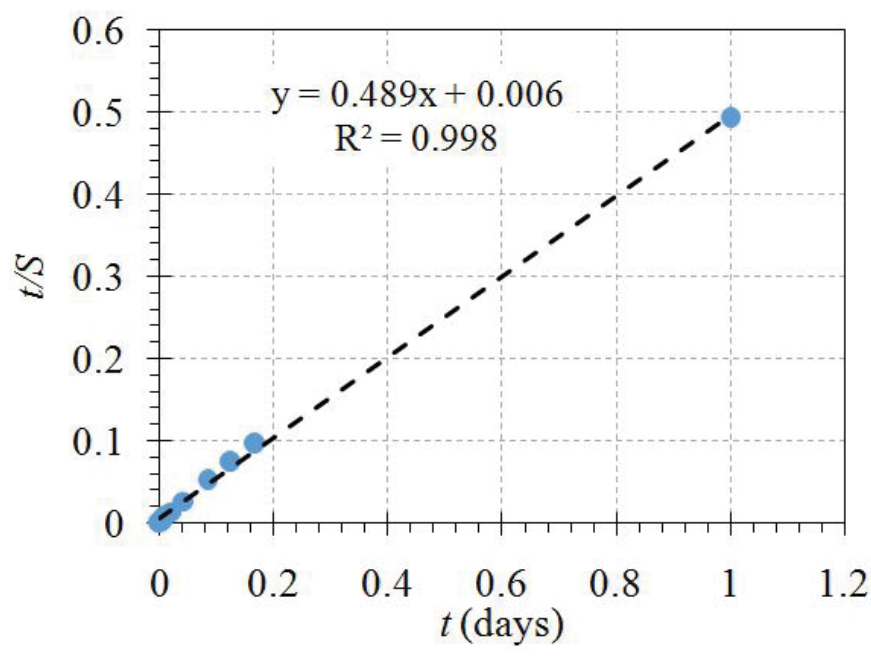

Figure 5: Coefficient $\alpha$ and $\beta$ from hyperbolic method

Estimated settlement at any stage of the embankment load calculated using Eq.(1) based on the coefficient $\alpha$ and $\beta$ derived from Figure 5. The results estimatedsettlement and its comparison with experimental data for peat with a bamboo grid shown in Figure 6 to Figure 10 . Results expected settlement looks to normalize patterns of settlement over time. 


\section{Table 1: Reduction of settlement}

\begin{tabular}{|c||c|c|c|c|c|c|c|}
\hline \multirow{2}{*}{$\begin{array}{c}\text { Time } \\
\text { (day) }\end{array}$} & \multicolumn{4}{|c|}{$\begin{array}{c}\text { Settlement, S (mm) } \\
\text { Bamboo } \\
\text { grid }\end{array}$} & \multicolumn{2}{|c|}{ Bamboo piles with space (s) } & \multicolumn{3}{c|}{ Reduction of settlement } \\
\cline { 2 - 8 } & $15 \mathrm{~cm}$ & $10 \mathrm{~cm}$ & $5 \mathrm{~cm}$ & $\mathrm{~s}=15 \mathrm{~cm}$ & $\mathrm{~s}=10 \mathrm{~cm}$ & $\mathrm{~s}=5 \mathrm{~cm}$ \\
\hline 1 & $20: 28$ & 19.72 & 16.91 & $10: 48$ & 2.76 & 16.62 & 48.32 \\
\hline 2 & 39.73 & 37.32 & 33.66 & $20: 19$ & $6: 07$ & $15: 28$ & 49.18 \\
\hline \hline 3 & 57.90 & 51.40 & 48.27 & 29.59 & $11: 23$ & 16.63 & 48.89 \\
\hline 4 & 74.00 & 67.00 & 62.01 & 38.84 & $10: 01$ & 16.71 & 47.83 \\
\hline 5 & 89.97 & 82.27 & 74.35 & 48.29 & $8: 56$ & $17: 36$ & 46.33 \\
\hline
\end{tabular}

$\begin{array}{llllllllllll}0 & 0.1 & 0.2 & 0.3 & 0.4 & 0.5 & 0.6 & 0.7 & 0.8 & 0.9 & 1\end{array}$

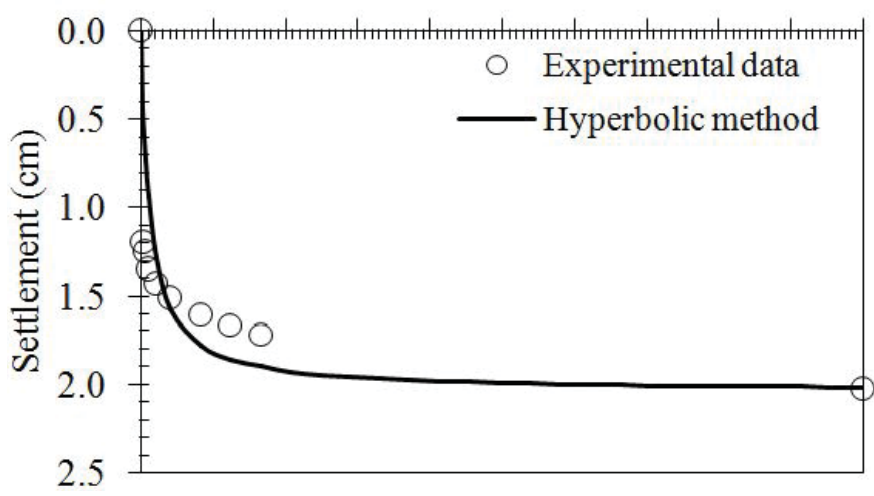

Figure 6: Settlement predicted on first embankment load

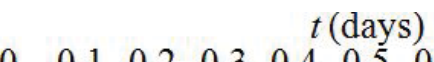

$\begin{array}{llllllllllll}0 & 0.1 & 0.2 & 0.3 & 0.4 & 0.5 & 0.6 & 0.7 & 0.8 & 0.9 & 1\end{array}$

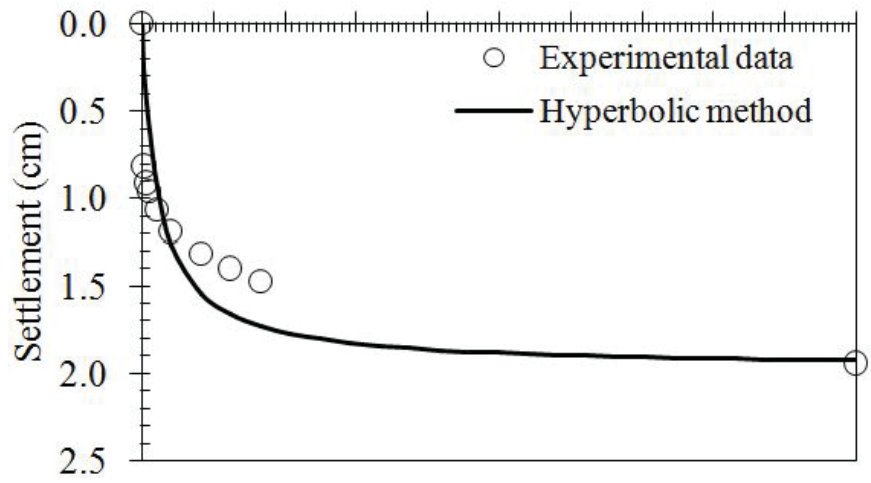

Figure 7: Settlement predicted on second embankment load $\begin{array}{lllllll} & t \text { (days) }\end{array}$

$\begin{array}{llllllllllll}0 & 0.1 & 0.2 & 0.3 & 0.4 & 0.5 & 0.6 & 0.7 & 0.8 & 0.9 & 1\end{array}$

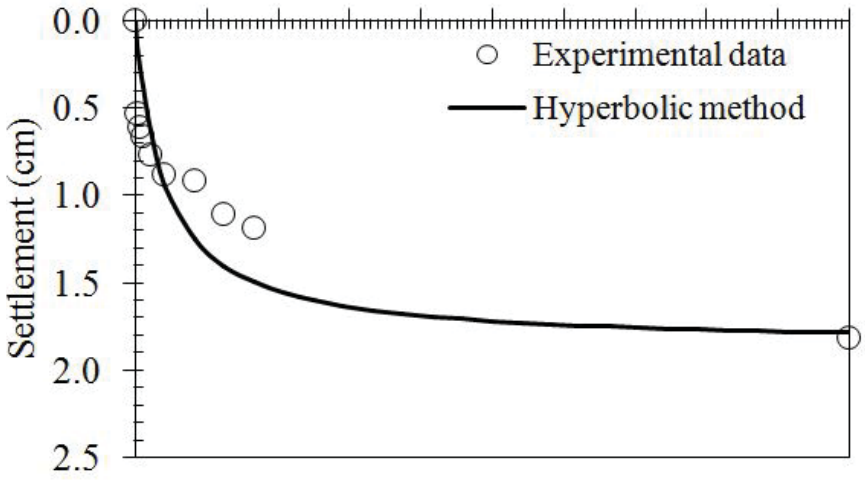

Figure 8: Settlement predicted on third embankment load

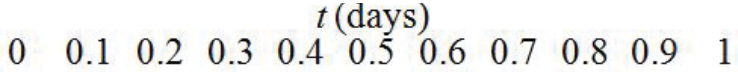

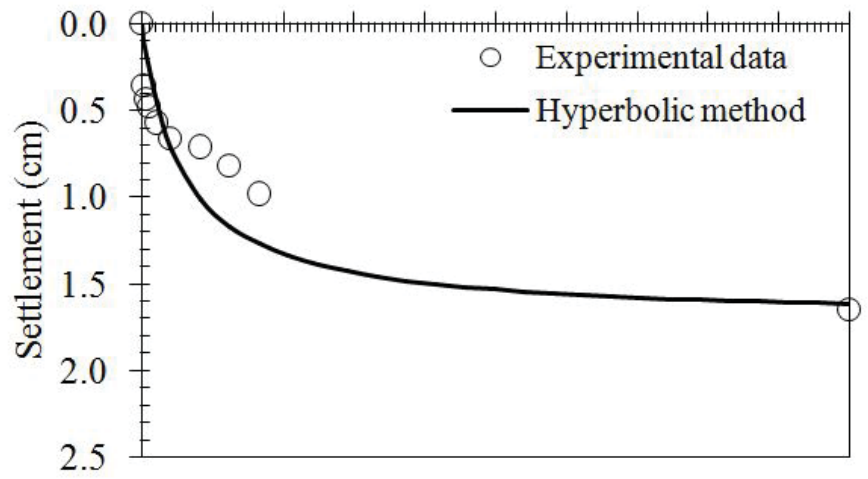

Figure 9: Settlement predicted on fourth embankment load 
Results of analysis $\alpha$ and $\beta$ shown in Figure 11.a and Figure 11.b. The $\alpha$ and $\beta$ coefficient can be attributed to stess from embankment load, this relationship is given in the form of the regression equation. The regression equation obtained can be used to estimate the $\alpha$ and $\beta$ coefficientson a larger embankment loads. The results of the estimated $\alpha$ and $\beta$ coefficient shown in Figure 11.c and Figure 11.d.

Estimated of a coefficient on any type of test is shown in Figure 12. Embankment load showed increase in the a coefficient, but for a bamboo pile to the ratio s/d of 2.5 shows that the a coefficient constant at a certain stess, this proves that the settlement has reached the maximum on any addition load.

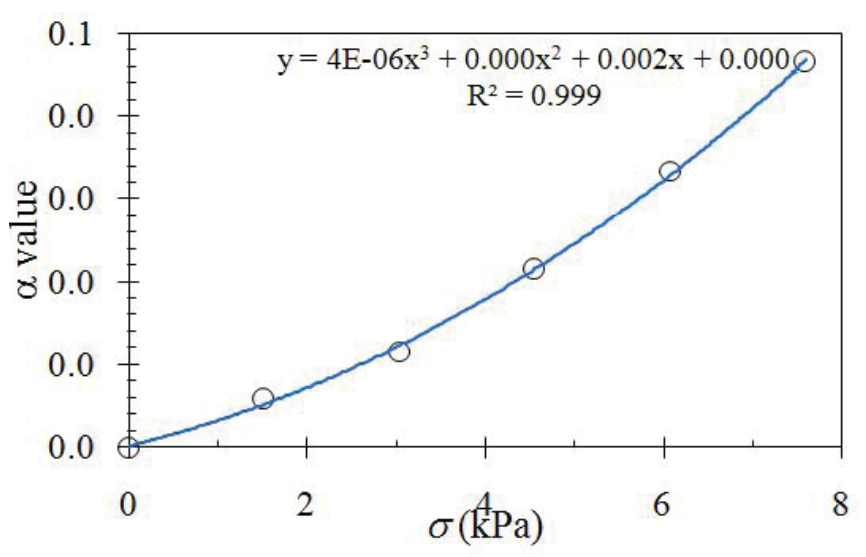

(a)

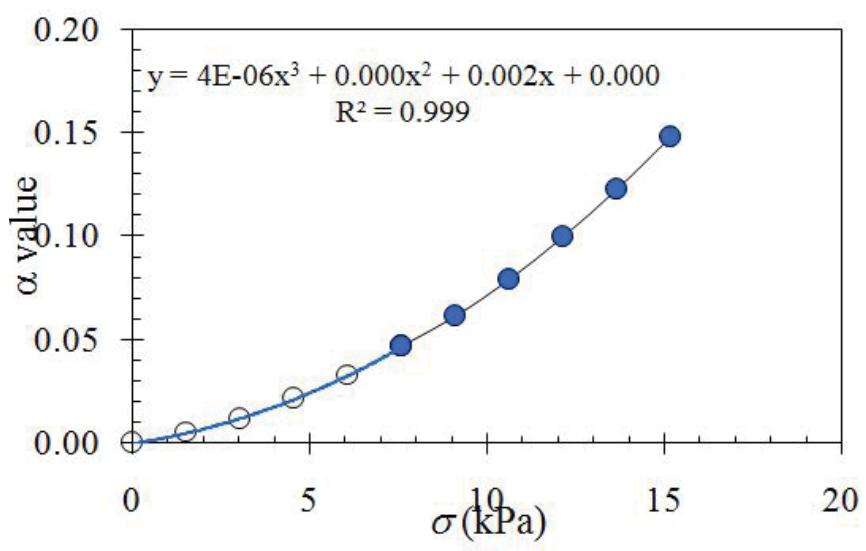

(c)

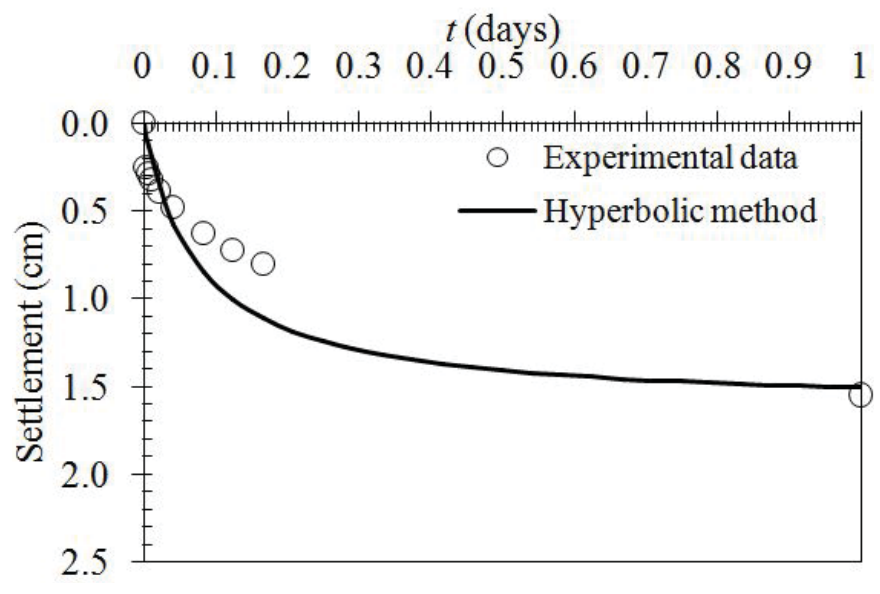

Figure 10: Settlement predicted on fifth embankment load

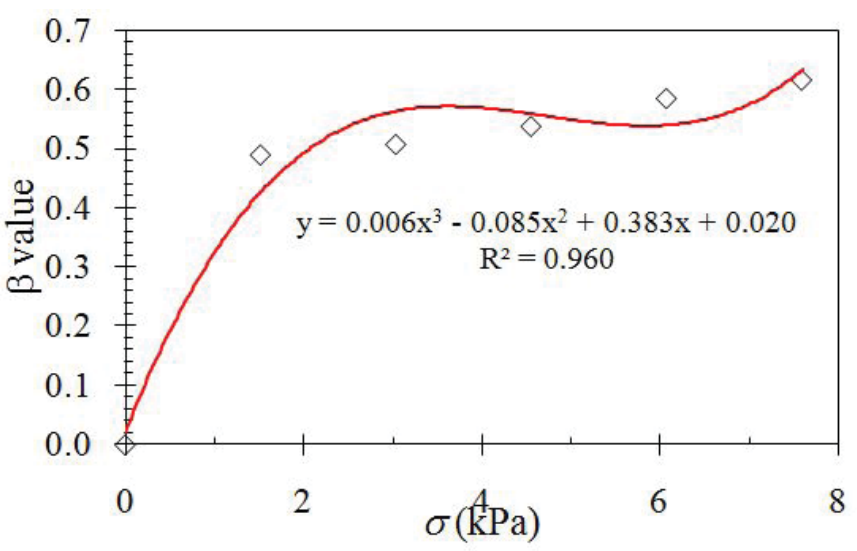

(b)

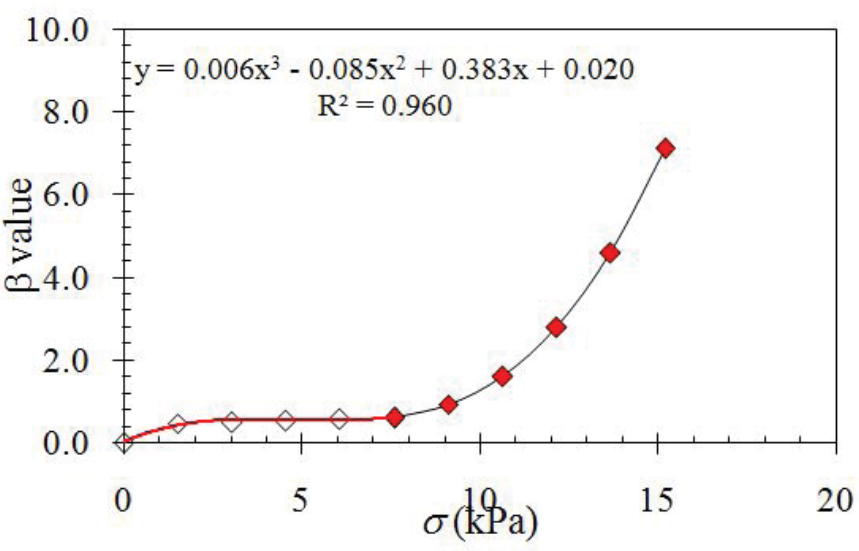

(d)

Figure 11: Estimation of the value of coefficient $\alpha$ and $\beta$ : (a) Correlation of coefficient $\alpha$ and embankment load; (b) Correlation of coefficient $\beta$ and embankment load; (c) Estimation of $\alpha$ value; and (d) 
In addition $\alpha$ coefficient increased, due to the addition of a embankment load seen that the $\beta$ coefficient increased (Figure 13). Increased $\alpha$ and $\beta$ coefficientshows that the smaller the value settlement. This may imply that the additional load can be further reduced heap additional settlement. Likewise with the increasingly dense pole spacing can reduce the settlement.

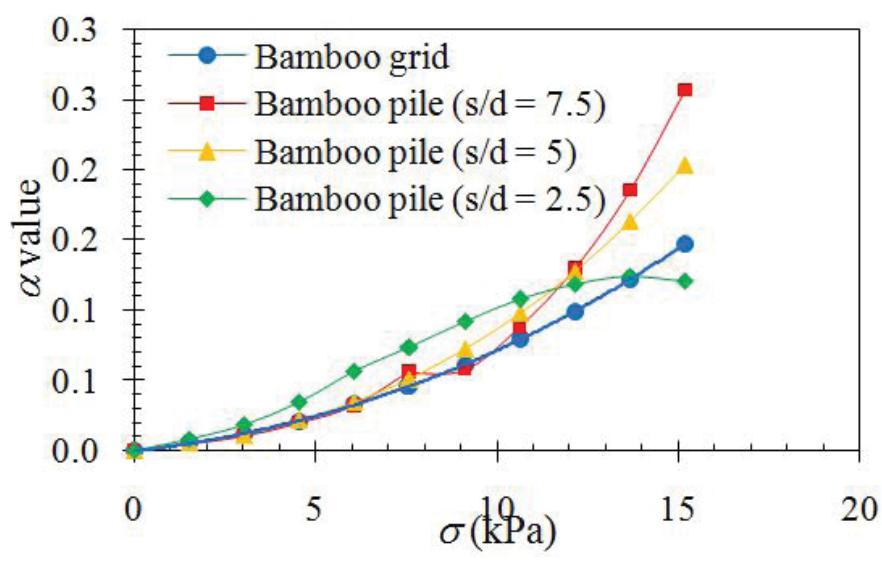

Figure 12: Effect of bamboo pile on a value

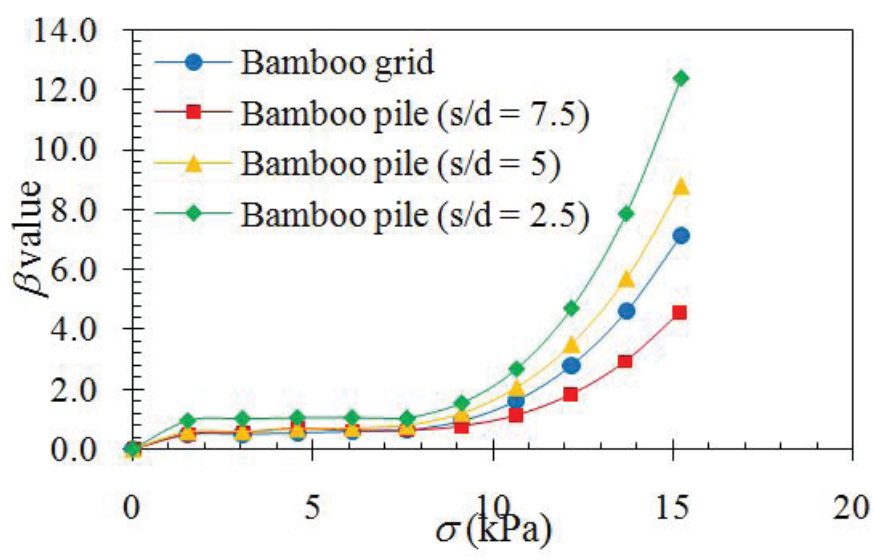

Figure 13: Effect of bamboo pile on $\beta$ value

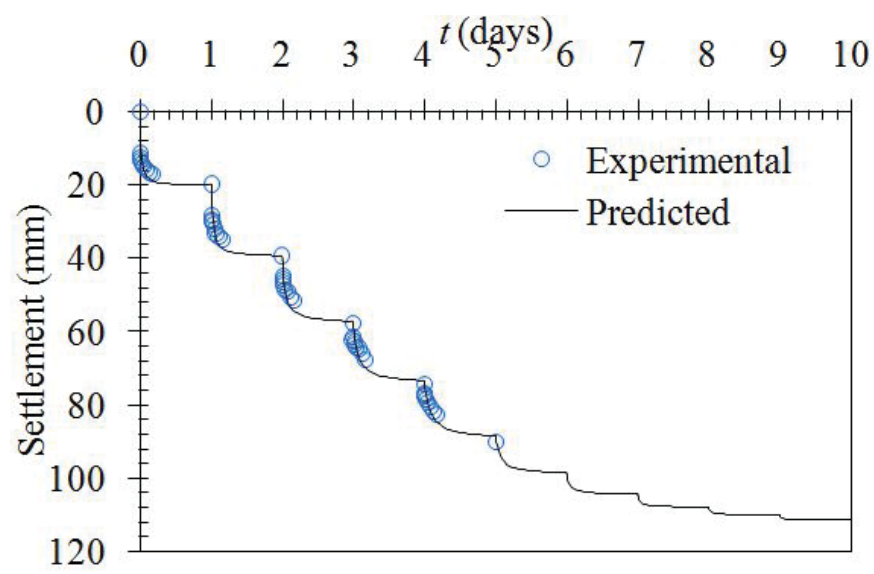

Figure 14: Settlement predicted of peat with bamboo grid

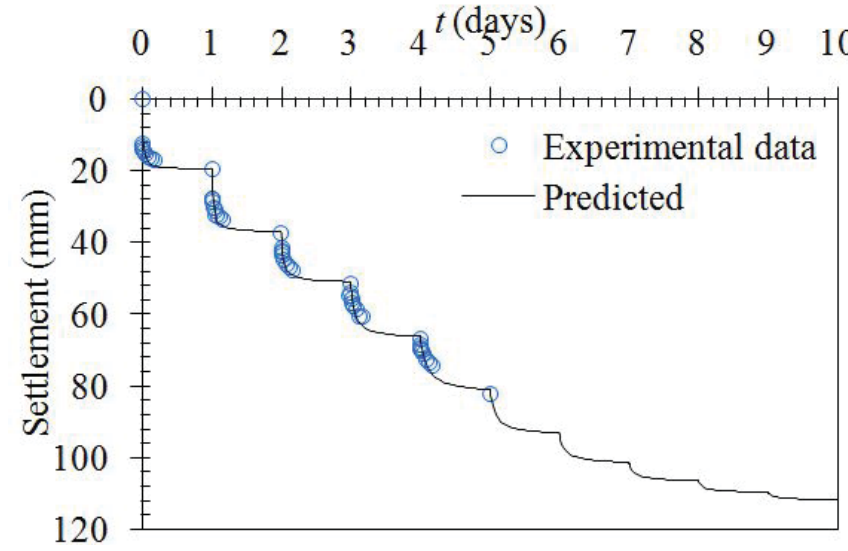

Figure 15: Settlement predicted of peat bamboo pile (s/d of 7.5$)$

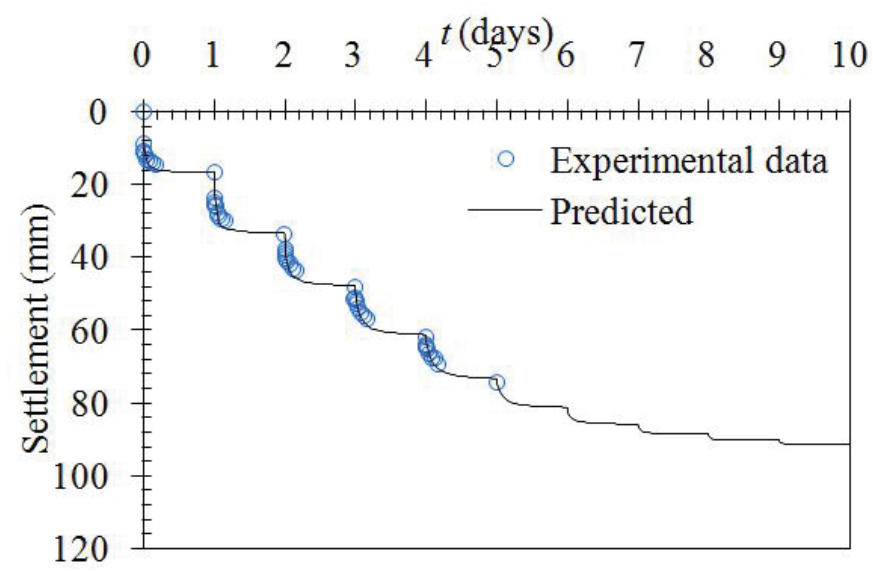

Figure 16: Settlement predicted of peat with bamboo pile (s/d of 5)

Based on the $\alpha$ and $\beta$ coefficients of Figure 12 and Figure 13 and using Eq.(1) obtained estimates of settlement in each type of test as shown in Figure 14 and Figure 17. Estimated settlement until the fifth day looks the same approach to the experimental data. If additional load applied on the same sixth to tenth, the pattern resembles the pattern seen a decrease in the settlement of the experimentalresults. Based on this pattern, then the time and large embankment load is applied on top of the peat soil can be estimated without waiting for the results of the completed embankment.

Full results from the estimatedsettlement in all types of testing are shown in Figure 18. This pattern of inheritance can give an idea of how long and how much load is applied to each type of test to get a change of the relatively small settlement. Differences settlementeach type of testing increasingly clear during the load over $9 \mathrm{kPa}$. Reinforcement a bamboo pile with a ratio of 2.5 and 5 show significant impact on the reduction settlement against the bamboo grid without pile dibandingkatn bamboo pile with ratio of 7.5 . 


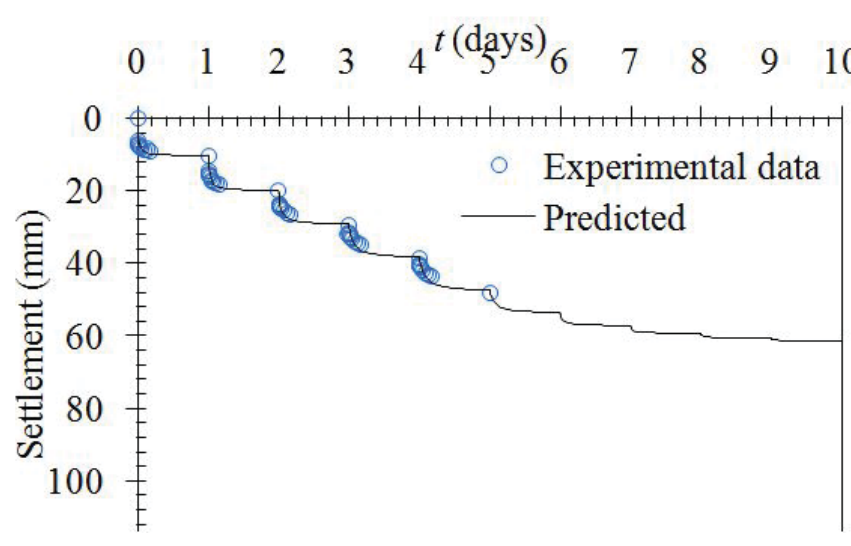

Figure 17: Settlement predicted of peat with bamboo pile (s/d of 2.5$)$

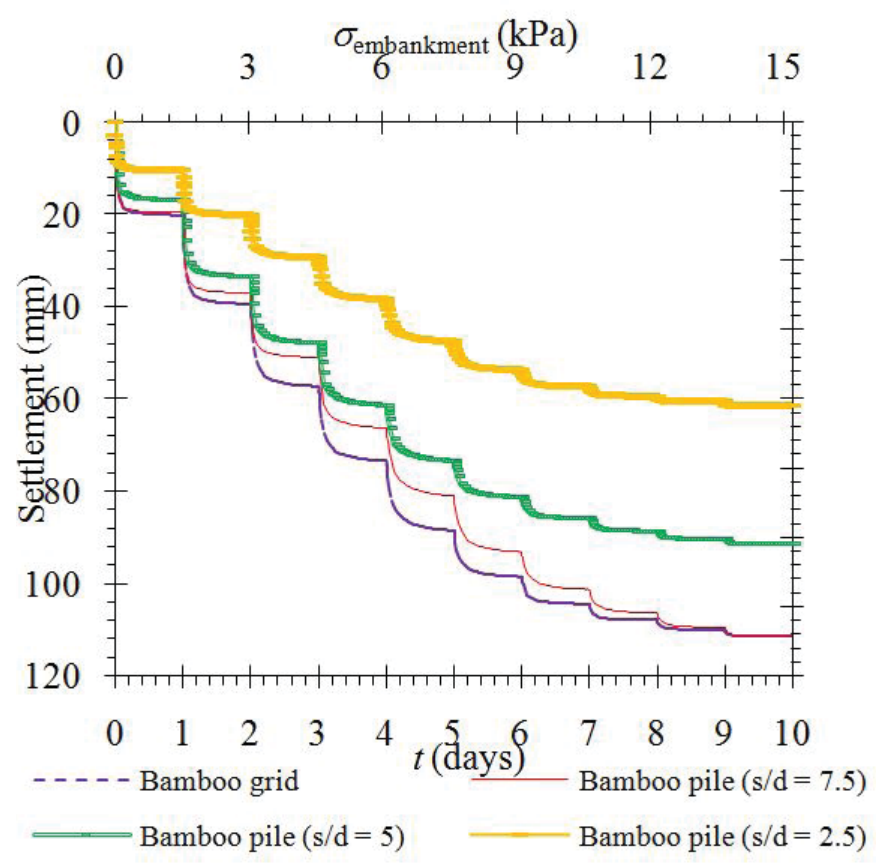

Figure 18: Result of estimation of settlement on peat due to embankment load

\section{CONCLUSION}

Significant compression change of peat occurs in the use of a bamboo pile to the ratio s/d of 2.5 , while the bamboo pile to the ratio s/dof 5 and 7.5 are not much different from the grid bamboo without pile bamboo. The analysis showed that the bamboo pile to the ratio s/dof 2.5 can reduce a significant settlement.

The ratio B/sof 15 provides a maximum settlement reduction of approximately $60 \%$. The ratio B/sof 15 obtained on the ratio s/dof 2 , thus the ratio s/d should be between $2-5$, it is approximately equal to the test results onreinforcement bamboo pile with a ratio s/dof2.5 and 5 compared bamboo pile with a ratio of 7.5.

Based on the pattern of settlementfrom the experimental data, the time and large embankment load is applied on the peat soil can be estimated without waiting for the re- sults of the completed embankment.

Based on the estimated $\alpha$ and $\beta$ coefficients on any plan of embankment load, then settlementevery plan embankment can be estimated. Results estimated settlement showed the same pattern with the pattern of inheritance of the experimental data. These results can estimate how long and how much load is applied to each type of test to get a change of the relatively small settlement.

\section{ACKNOWLEDGMENTS}

The authors would like to thank the Directorate of Research and Community Service - Directorate General of Research and Development Strengthening - Ministry of Research, Technology, and Higher Education of the Republic of Indonesia for supporting this research.

\section{REFERENCES}

1. Anusha, R. dan Kindo, E. C. (2011). Behaviour of Bamboo Reinforced Soils - State of Art, Proceedings of Indian Geotechnical Conference December 15-17, 2011, Kochi (Paper No. H-247).

2. Kandolkar, S. S., \& Mandal, J. N. (2012). Behaviour of mine waste as reinforced soil. International Journal of Reseach in Engineering and Technology, 1(2), 82-89.

3. Liu, H. L., Ng, C. W. W., dan Fei, K., 2007. Perfomance of a Geogrid-Reinforced and Pile-Supported Highway Embankment over Soft Clay: Case Study, Journal of Geotechnical and Geoenvironmental Engineering, ASCE, 13(12) : 1483-1493.

4. Marto, A., \& Othman, B.A. (2011). The potential use of bamboo as green material for soft clay reinforcement system. International Conference on Environment Science and Engineering, Singapore, (pp. 129133).

5. Maulana, Azwar, Susanti, R. D., \& Waruwu, A. (2018). Potential of bamboo pile as reinforcement of peat soil under embankment. ARPN Journal of Engineering and Applied Sciences, 13(1), 52-56.

6. Porbaha, A., Hanzawa, H., dan Kishida, T., 2000. Analysis of A Failed Embankment on Peaty Ground. In Slope Stability, (pp. 281-293).

7. Susanti, R. D., Maulana, Waruwu, A. (2017). Bearing capacity improvement of peat soil by preloading. ARPN Journal of Engineering and Applied Sciences, 12(1), 121-124.

8. Tan, T.S., Inoue, T., dan Lee, S.L. 1991. Hyperbolic Method for Consolidation Analysis. Journal of Geotechnical Engineering, 117(11), pp.1723-1737.

9. Toh, C.T., Chee, S.K., Lee, C.H., dan Wee, S.H., 1994. Geotextile-Bamboo Fascine Mattress for Filling over Very Soft Soils in Malaysia. Geotextiles and Geomembranes, 13(6-7), pp.357-369. 
10. Waruwu, A., Hardiyatmo, H. C., \& Rifa'i, A. (2016). Compressive behavior of Bagansiapiapi-Riau peat in Indonesia. Electronic Journal of Geotechnical Engineering, 21(16), 5217-5227.

11. Waruwu, A. Maulana, \& Halim, H. (2017). Settlement estimation of peat reinforced with bamboo grid under embankment. International Review of Civil Engineering (I.RE.C.E.), 8(6), 299-306.
12. Waruwu, A., Hardiyatmo, H. C., \& Rifa'i, A. (2017). Deflection behavior of the nailed slab system-supported embankment on peat soil. Journal of Applied Engineering Science, 15(4), 556-563.

13. Waruwu, A., Halim, H., Nasution, T., dan Hanova, Y., 2018. Bamboo Grid Reinforcement on Peat Soil under Repeated Loading. Journal of Engineeering and Applied Sciences, 13(8): 2190-2196. 